\title{
What Is Refractory Organic Matter in the Ocean?
}

\author{
Federico Baltar ${ }^{1 *}$, Xosé A. Alvarez-Salgado ${ }^{2}$, Javier Arístegui ${ }^{3}$, Ronald Benner 4 , \\ Dennis A. Hansel/5, Gerhard J. Herndl ${ }^{1,6}$ and Christian Lønborg ${ }^{7}$
}

\begin{abstract}
${ }^{1}$ Department of Functional and Evolutionary Ecology, University of Vienna, Vienna, Austria, ${ }^{2}$ Instituto de Investigaciones Marinas-Centro Superior de Investigaciones Cientificas (IIM-CSIC), Vigo, Spain, ${ }^{3}$ Instituto de Oceanografía y Cambio Global (IOCAG), Universidad de Las Palmas de Gran Canaria, Las Palmas, Spain, ${ }^{4}$ Department of Biological Sciences, School of the Earth, Ocean and Environment, University of South Carolina, Columbia, SC, United States, ${ }^{5}$ Department of Ocean Sciences, Rosenstiel School of Marine and Atmospheric Science, University of Miami, Miami, FL, United States, ${ }^{6}$ Neutlands Institut voor Zeeonderzoek (NIOZ), Department of Marine Microbiology and Biogeochemistry, Royal Netherlands Institute for Sea Research, Utrecht University, Utrecht, Netherlands, ${ }^{7}$ Section for Applied Marine Ecology and Modelling, Department of Bioscience, Aarhus University, Aarhus, Denmark
\end{abstract}

About $20 \%$ of the organic carbon produced in the sunlit surface ocean is transported into the ocean's interior as dissolved, suspended and sinking particles to be mineralized and sequestered as dissolved inorganic carbon (DIC), sedimentary particulate organic carbon (POC) or "refractory" dissolved organic carbon (rDOC). Recently, the physical and biological mechanisms associated with the particle pumps have been revisited, suggesting that accepted fluxes might be severely underestimated (Boyd et al., 2019; Buesseler et al., 2020). Perhaps even more poorly understood are the mechanisms driving rDOC production and its potential accumulation in the ocean. On the basis of recent conflicting evidence about the relevance of DOC degradation in the deep ocean, we revisit the concept of rDOC in terms of its "refractory" nature in order to understand its role in the global carbon cycle. Here, we address the problem of various definitions and approaches used to characterize rDOC (such as turnover time in relation to the ocean transit time, molecule abundance, chemical composition and structure). We propose that rDOC should be operationally defined. However, we recognize there are multiple ways to operationally define rDOC; thus the main focus for unifying future studies should be to explicitly state how rDOC is being defined and the analytical window used for measuring rDOC, rather than adhering to a single operational definition. We also conclude, based on recent evidence, that the persistence of rDOC is fundamentally dependent on both intrinsic (chemical composition and structure, e.g., molecular properties), and extrinsic properties (amount or external factors, e.g., molecular concentrations, ecosystem properties). Finally, we suggest specific research questions aimed at stimulating research on the nature, dynamics, and role of rDOC in Carbon sequestration now and in future scenarios of climate change.

Keywords: dissolved organic matter, dissolved organic carbon, refractory DOC, carbon cycle, climate change

\section{INTRODUCTION}

Marine ecosystems play a central role in global biogeochemical cycles and climate by sequestering carbon (C) in the deep ocean. Air/sea gas exchange processes are mainly responsible for anthropogenic dissolved inorganic carbon (DIC) sequestration, particularly at high-latitudes where cold surface waters have increased gas solubility and a fast overturning to the deep ocean 
(the so-called "solubility pump"; SP). However, biotic processes, such as mediated by the "biological carbon pump" (BCP), explain the majority (ca. 90\%) of the vertical distribution of natural DIC in the water column. During the ocean transit time the SP sequesters DIC via global overturning circulation, while biotic processes store carbon in the deep ocean either as DIC, sedimentary particulate organic carbon (POC) or dissolved organic carbon (DOC). The amount of DOC in oceanic waters amounts to ca. 660 million metric tons of carbon (660 Pg C), comparable to the $\mathrm{CO}_{2}$ currently present in the atmosphere (860 Pg C) (Hansell, 2013; Friedlingstein et al., 2019). DOC is the largest reservoir of reduced $\mathrm{C}$ in the oceanic water column, holding $>200$ times the $\mathrm{C}$ inventory of marine biomass (Hansell, 2013; Figure 1). This mass is comparable to the amount of particulate organic C (POC) accumulated in marine sediments (about $1,000 \mathrm{Pg} \mathrm{C}$ ) in the last 5,000-10,000 years (Perdue and Benner, 2009). A large fraction of this DOC pool is apparently "non-accessible" or "resistant" to rapid microbial degradation, leading to the adjective "refractory" to describe it (rDOC). Due to its large inventory (ca. $640 \mathrm{Pg} \mathrm{C}$ ) and long-term stability (Dittmar, 2015), rDOC is one of the cornerstones in marine organic $\mathrm{C}$ sequestration (Figure 1). However, despite the importance of this pool, there are conflicting views and unclear uses of the term "refractory"; these inconsistent connotations impede communication and interpretation of research results and thus projections of $\mathrm{C}$ fluxes and sequestration. In this respect, Hansell (2013) commented on the confusing nomenclature used for defining this major DOC fraction:

"The problem is exemplified in the denotations of a word commonly used by the marine science community, "refractory" (...). The marine science community does not employ the word by its denotation, nor has it agreed on a common connotation. As an adjective, refractory has described the resistance of organic matter to biological remineralization (...) and to chemical oxidation (...), and has been used to characterize DOC that accumulates during culture incubations (...). It has been alternatively employed as a noun in naming the oldest and most abundant fraction of DOC in seawater (...). These forms of DOC do not have identical reactivities, yet they have all been termed refractory."

To address this issue, Hansell (2013) introduced a classification of the DOC pool based on its lifetime or reactivity: labile, semi-labile, semi-refractory, refractory, and ultra-refractory DOC, each of which is characterized by

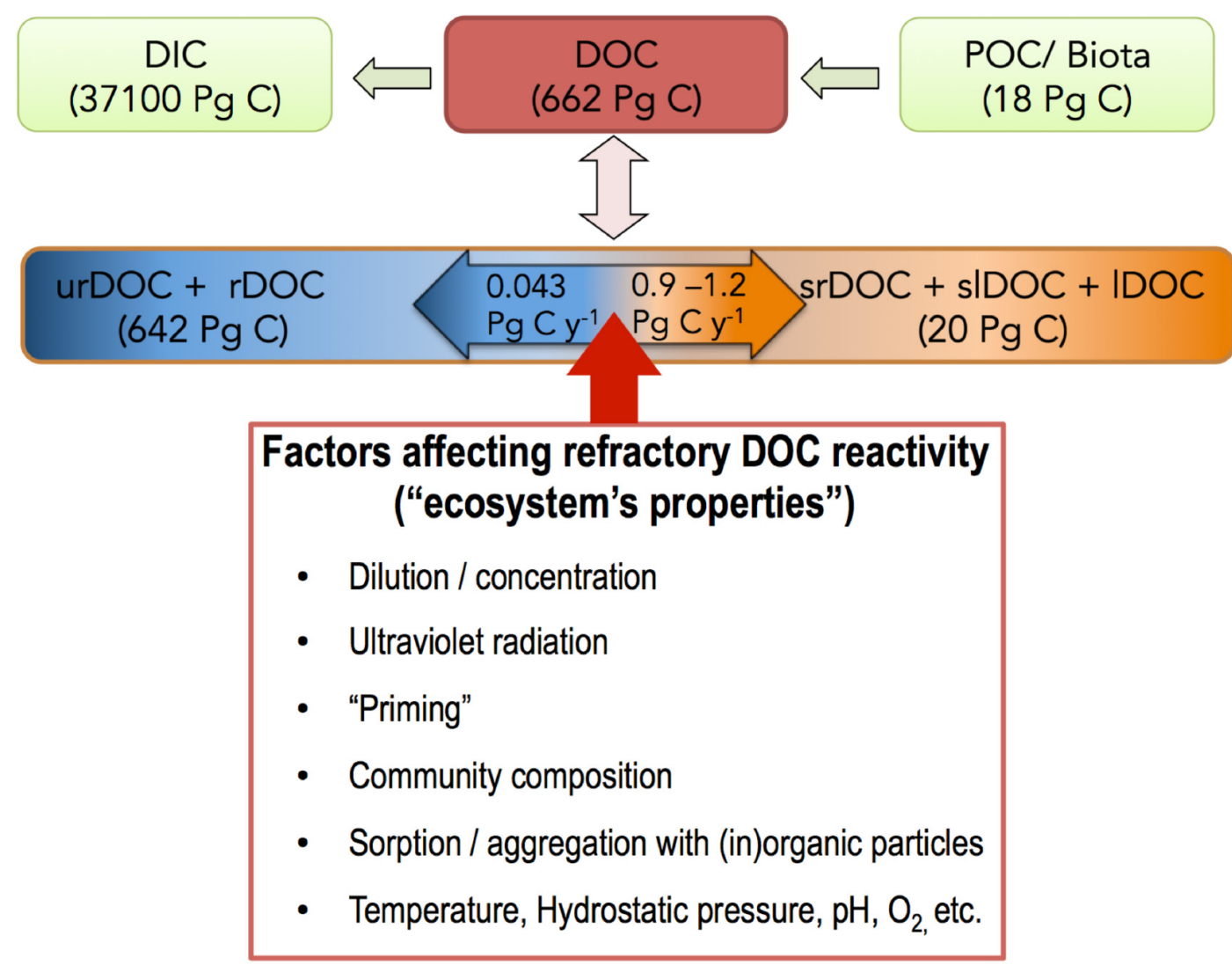

FIGURE 1 | Diagram showing major carbon stocks in the ocean, including a list of the main factors affecting reactivity of the refractory (rDOC) pool. The DOC inventory in the global ocean is ca. $662 \mathrm{Pg} \mathrm{C}$ (Hansell, 2013). The POC/marine biota pool is ca. $18 \mathrm{P} \mathrm{g} \mathrm{C}$, including 1-3 Pg C phytoplankton, $0.1 \mathrm{Pg}$ C zooplankton, $0.1 \mathrm{Pg} \mathrm{C}$ bacteria and $15 \mathrm{Pg} \mathrm{C}$ of detritus (Perdue and Benner, 2009). Short-lived DOC has a pool size of about 20 Pg C (662-642 Pg C). DIC: dissolved inorganic carbon, DOC, dissolved organic carbon; POC, particulate organic carbon; urDOC, ultra-refractory DOC; rDOC, refractory DOC; srDOC, semi-refractory DOC; sIDOC, semilabile DOC; IDOC, labile DOC. 
distinctive ocean residence times. Although this classification has proven useful in the study of oceanic DOC, it has not completely avoided the core problem, which is the use of the term "refractory" as a one-fits-all word for different and frequently non-complementary properties/characteristics related to DOC reactivity. Another way of addressing the reactivity of DOC is to use the DOC continuum concept instead of using a number of DOC pools based on its reactivity (Zakem et al., 2021). Several studies have discussed DOC reactivity in terms of compounds with a continuum of first order decay rates, e.g., in sediments (Boudreau and Ruddick, 1991; Middelburg et al., 1993) and lake water (Vähätalo et al., 2010; Koehler et al., 2012).

Yet, a major reason precluding a robust definition and utilization of the adjective "refractory" in describing DOC is our limited knowledge of its complex nature. The current conceptual framework explaining the mechanisms governing the formation and mineralization of $\mathrm{rDOC}$ is the "size-reactivity continuum model." This model refers to the inverse relationship between the molecular size of DOC components and their bioavailability, i.e., larger size classes of DOC are more bioavailable to heterotrophic microbes than the bulk of small molecules (Amon and Benner, 1996). Consistent with this model, based on laboratory incubations with natural microbial communities, studies of the chemical composition and radiocarbon $\left(\Delta^{14} \mathrm{C}\right)$ content confirm that the complexity and age of DOC increases with decreasing molecular size (Walker et al., 2016; Broek et al., 2020.). This relationship suggests that microbial degradation controls the size distribution and the nature of the small DOC molecules persisting in the ocean (Benner and Amon, 2015; Walker et al., 2016; Broek et al., 2020). Advances in mass spectrometry (i.e., Fourier transform ion cyclotron resonance mass spectrometry, FT-ICR-MS) reveal an astonishing diversity of molecules in the DOC pool, with thousands of different molecular formulae (Lechtenfeld et al., 2014; Hansman et al., 2015; Zark and Dittmar, 2018). These analyses do not capture the full extent of the molecular diversity and complexity of molecules comprising rDOC because FT-ICR-MS analyses require previous isolation of DOC from seawater; the commonly used solid phase extraction methods are chemically selective, typically recovering less than half of the total DOC. Mass spectrometry also requires ionization of the molecules, creating a further bias (Patriarca et al., 2020). It is worth mentioning that the experiments referred to for the "size-reactivity continuum model" include very few size fractions (i.e., 2 fractions inAmon and Benner (1996), MartínezPérez et al. (2017), Broek et al. (2020) and 4 fractions in Walker et al. (2016), which is similar to a bulk group approach (refractory vs. labile). However, also these approaches have methodological limitations such as size fractions determined by the pore size of the membranes used.

To understand the term "refractory," it is important to consider three approaches currently used to characterize the pool: (1) the pool's longevity (e.g., Hansell, 2013); (2) the occurrence of specific molecular compositions and structures (i.e., molecular properties) possibly unrecognizable by prokaryotic enzymes or requiring many enzymes to degrade it, hence yielding a low energetic benefit (Jiao et al., 2010; Lechtenfeld et al., 2015); and (3) the extreme dilution of individual compounds, precluding energetically efficient degradation (Arrieta et al., 2015). It is generally assumed that these "typologies" are complementary, meaning that when we refer to one, the other two are included (Figure 2A). However, this is not necessarily the case as, for instance, there are examples of complex organic compounds that, although requiring hundreds of enzymes to be degraded, are consumed within days under certain conditions (Sichert et al., 2020). Astonishingly, few actual molecules constituting DOM have been isolated and their reactivity tested (Hertkorn et al., 2006; Geuer et al., 2019; Petras et al., 2021). Moreover, the term rDOC is strongly dependent on ecosystem properties, with compounds being "refractory" in one and degraded in other environments or conditions (Ward et al., 2013; Bianchi et al., 2018; Figure 1). For example: (i) ultraviolet radiation can transform DOC compounds from recalcitrant to bioavailable and vice versa (Benner and Biddanda, 1998; Obernosterer et al., 1999; Mopper et al., 2015; Shen and Benner, 2018; Sun et al., 2021); (ii) "Priming," with the addition of highly bioavailable compounds, may result in enhanced degradation of more refractory compounds (Bianchi, 2011; Shen and Benner, 2018), although the process is controversial outside of soil science (Catalán et al., 2015; Bengtsson et al., 2018); (iii) rDOC that is resistant to degradation by the microbial community of a given ecosystem can be utilized by microbes of another ecosystem (Carlson et al., 2004; Shen and Benner, 2018); (iv) hydrostatic pressure can deform enzymes, making them less effective in cleaving substrates (Penniston, 1971); (v) sorption and aggregation with "(in)organic particles" might hamper degradation in specific settings while stimulating degradation in others similar to soil (Keil and Mayer, 2014). Labile compounds might become less reactive if adsorbed to clay or held under anaerobic conditions, such as with ancient DNA (Lützow et al., 2006). Likewise, sinking particles release DOC (Lopez et al., 2020), and perform non-selective preservation, particularly when ballasted with terrigenous minerals (Druffel et al., 1992; Hedges et al., 2001). Thus, taken together, what apparently is "refractory" for a particular environment, population or community is not necessarily in a "stable state" or inert (Figure 1). This outcome is not surprising bearing in mind that biochemical reactions always require certain conditions, whether it is due to their activation energy (affected by catalysts/enzymes), their state (gas/water/ice) or the availability of reactants (concentration). The challenge now resides in bringing the empirical evidence back into chemical and biochemical theory (Kothawala et al., 2020).

Collectively, these examples indicate that the three descriptors of "refractory" DOC do not always refer to the same property. Therefore, a better representation of their relation/association may be a Venn diagram (Figure 2), where in some cases two or more descriptions fit the same compound whereas at other times or in other environments there will be no complementarity whatsoever. While definition (1) is "operational," definitions (2) and (3) are more "conceptual." Definition (1) is easier to apply by both microbiologists and biogeochemists. For a microbiologist, rDOC would be the fraction that escapes degradation at the end of the experiment (which ideally should last several years). For a biogeochemist, rDOC is the fraction that has a turnover time that exceeds the transit time of the water mass under study, 




Empirical
B

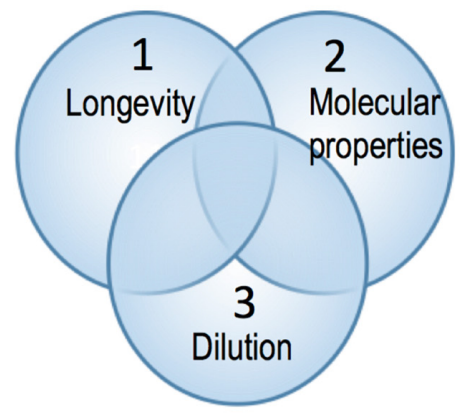

Conceptual
C

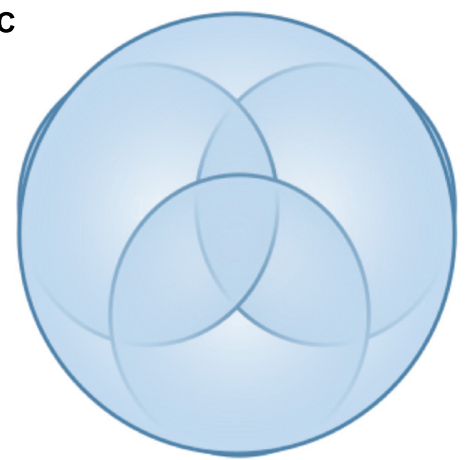

Theoretical

FIGURE 2 | Diagram showing different levels of relationship of three currently employed characteristics, properties and definitions (i.e., 1, 2, and 3) of "refractory" DOC (see text for details): (A) the case in which the three definitions are complementary, (B) the case where the three definitions are sometimes complementary for some compounds under specific environmental conditions. Part (A) is empirical, part (B) is conceptual. The ultimate goal of our research is represented by the integrative part $\mathbf{( C )}$, related to biochemical theory for individual molecules.

which can last from months in the coastal ocean to about one thousand years in the deep open ocean (Carlson et al., 2010; Lønborg and Álvarez-Salgado, 2012). Although definitions (2) and (3) can be complementary, they can also exclude each other. If a molecule is unaltered by biological or geochemical processes it will be refractory independent of its concentration. In contrast, very labile molecules such as amino acids can be preserved only if they are extremely diluted at ca. $10^{-12} \mathrm{~mol} \mathrm{~L}^{-1}$ (Williams, 2000). At this point, it becomes clear that we not only have a clear gap of knowledge on the real nature of rDOC, but also contrasting perspectives depending on our approach to studying and interpreting the DOM transformation (i.e., microbiologists vs. geochemists). These differing perspectives are a pressing problem that we need to resolve for understanding oceanic DOC.

Early studies of DOC reactivity (Ogura, 1970, 1972) defined rDOC as "not easily utilized by microorganisms." Based on this definition, there are many types of rDOC compounds in the major nonliving reservoirs of organic matter (aquatic and terrestrial). Refractory organic matter is considered resistant to biodegradation but it is not considered inert. If, by definition, we assume that rDOC is not significantly degraded on a time scale of decades to millennia (Hansell, 2013), and that the pool is biologically produced (Jiao et al., 2010; Legendre et al., 2015; Osterholz et al., 2015), either steady state or accumulation of rDOC over time would be plausible. Yet, to fully address this question of net DOC accumulation in the global ocean we would need to know the drivers and mechanisms of rDOC production and removal. Ocean mixing and circulation are important for transporting rDOC to different areas of the ocean where conditions may be favorable for removal (Hansell and Carlson, 2013). It might be that the ocean overall is in "steady state" (i.e., sources equal long-term sinks). Geochemical evidence indicates that the rDOC pool in the ocean undergoes slow degradation (time scales of deep ocean circulation or longer), but is renewed at the time scale of surface ocean circulation (Hansell, 2013). This description is supported by recent evidence from microbiologists on $\mathrm{rDOC}$ production rates indicating that it is produced faster than it is consumed. For instance, recent laboratory experiments show that natural bacterial communities (Lechtenfeld et al., 2015) and marine archaeal isolates (Bayer et al., 2019) produce significant amounts of carboxyl-rich alicyclic molecules (CRAM) over a period of weeks. The CRAM may be key contributors to the rDOC pool (Hertkorn et al., 2006). CRAM has been shown to be removed in hydrothermal vent systems (Hawkes et al., 2015), although the water flux in vent systems appears to be too low to explain the apparent steady state (Hawkes et al., 2015). A further example is petroleum: it is preserved for millions of years; however, when it seeps from sediments it is rapidly degraded by marine microbes (Valentine et al., 2010). Another such example is the microbial degradation and utilization of formate to sustain microbial growth, even though the molecule offers an extremely low energy yield (Dolfing et al., 2008). In any case, if rDOC is mostly non-degradable, one should expect "recently" produced rDOC to be a dominant and potentially accumulating fraction of DOC in the global ocean. According to global ocean model results, keeping the deep ocean rDOC pool in steady-state requires the injection of $0.043 \mathrm{Pg}$ C year ${ }^{-1}$ from the surface ocean (Hansell, 2013). However, a biological production of rDOC ranging between 0.1 and $0.2 \mathrm{Pg}$ C year ${ }^{-1}$ has been recently suggested (Legendre et al., 2015; Walker et al., 2016), which would point to the non steady-state of rDOC or that currently unknown sinks balance the pool. The annual increase of the $640 \mathrm{Pg} \mathrm{C}$ pool of rDOC at these latter rates would be $0.02-0.03 \%\left(0.13-0.19 \mathrm{Pg} \mathrm{C}_{\text {year }}{ }^{-1}\right)$ or $1.0-$ $1.5 \%(6.4-9.6 \mathrm{Pg} \mathrm{C})$ in 50 years, which is within the current error of the DOC measurements. Hence, we might not observe accumulation because the current measurements of DOC are not sufficiently sensitive.

Another consideration is the interpretation of bulk $\mathrm{DO}^{14} \mathrm{C}$ ages: if $30 \%$ of the DOC pool turns over in 1 year and the remaining $70 \%$ turns over in 8,000 years, the average age of the DOC pool will turn over in 5,600 years-a commonly observed 
age of bulk DOC in the deep ocean. Also, there are several sources of ${ }^{14} \mathrm{C}$-dead organic carbon to the ocean (e.g., petroleum seeps, hydrates, riverine discharge, etc.), further complicating the use of ${ }^{14} \mathrm{C}$ to determine the age of bulk DOC. Recent bioassay experiments indicate some deep ocean rDOC components are very resistant to microbial utilization due to their molecular properties (Shen and Benner, 2020), but different approaches are needed to determine whether these components are refractory to microbial removal over time scales of decades to centuries.

Based on the examples provided above, it is clear that there is a "terminology issue" that needs to be considered. The interested research community seeks to understand the controls on $\mathrm{C}$ sequestration (in other words, "refractory" compounds) while not really knowing what defines the reservoir. Given this conundrum, the word "refractory" should be used within the realm of current methodology and understanding. The inconsistent use of words leads to confusion, which makes it difficult to explore and quantify $\mathrm{C}$ sequestration.

This analysis shows that we still know very little about the refractory (strictly speaking) nature of DOC in the deep ocean. Is remineralization of DOC constrained by the composition and structure of the molecules, by concentration, by temperature, by hydrostatic pressure or by a combination of all factors to varying degrees? Recent studies have demonstrated microbial degradation of more recalcitrant compounds having higher temperature sensitivity, suggesting that ocean warming could reduce the $\mathrm{rDOC}$ pool size and lead to the production of $\mathrm{CO}_{2}$ (Lønborg et al., 2016, 2018). Another issue is that bacterial growth is stimulated upon decompression of deep-water samples, even if in situ temperature is maintained, indicating that relieving deepsea microbial communities from hydrostatic pressure stimulates DOC consumption (Amano et al. unpubl. data).

These few examples highlight our lack of knowledge on the ability of microbes to remineralize DOC, and the need to properly define/delimit rDOC. We propose that the word "refractory" should be operationally defined (e.g., any form of organic carbon that sequesters $\mathrm{CO}_{2}$ for a period longer that the ocean transit time under in situ conditions). It is important to recognize that this operational definition includes removal of rDOC by abiotic as well as biotic processes. Abiotic removal processes include sorption, photochemical degradation and thermal combustion in hydrothermal vent systems (Hansell, 2013; Hansell and Carlson, 2014). The term rDOC should be operational mainly because it is empirical, and because of the various potential removal processes and the varying capacity of microbes to degrade it (i.e., with respect to different species, molecular properties, dilution effects, temperature, hydrostatic pressure, etc.). DOC research is generally fraught with vague terminology (e.g., humic-like, labile, autochthonous), posing major challenges in comparing different studies and for large-scale data synthesis. The methodological approaches used to characterize oceanic rDOC have constantly expanded and diversified to keep pace with the growing interest in $\mathrm{rDOC}$ over the years. Thus, $\mathrm{rDOC}$ is an emergent property that is also operationally defined by the approach and/or method we use to quantify and characterize it. Therefore, we argue that the main focus in unifying future studies should be to explicitly state how rDOC is being defined and the analytical window used for measuring the pool, rather than adhering to a single operational definition. Leaving space for multiple (but clearly described) definitions of rDOC would promote collaborative efforts and allow for more efficient data synthesis. An empirical definition of "refractory" will prove useful because the DOC pool is a black box; theories about how it reacts or is degraded remain challenging to formulate. Nevertheless, we advocate for more theoretical approaches aiming to explain this resistance based on molecular structure (Kothawala et al., 2020). This suggestion is unlikely to lead to an unambiguous decision on whether a molecule is "refractory or not," but rather a determination as to "how refractory each molecule is." Whether we treat $\mathrm{rDOC}$ as reactivity groups or continua we will still reach the same solution: DOC is a mixture of a very large number of low concentration compounds, each exhibiting specific reactivity (decay rate and conditions required). Thus, critical knowledge could be gained from focusing on specific molecules.

Finally, to determine the relative importance of the variety of mechanisms contributing to accumulation and/or maintenance of the rDOC pool, we encourage pursuing the following research topics, all of which require close collaboration between microbiologists and biogeochemists:

(i) Cross-comparison among different analytical methods for isolation and characterization of rDOC in the ocean for understanding the possible unifying characteristics and molecular structure of rDOC.

(ii) Focus on the mechanisms of production and removal of rDOC in intermediate and deep-water formation areas.

(iii) Studies linking chemical diversity of rDOC to microbial diversity, identifying associations between the production and removal of rDOC with specific bacterial and archaeal groups (Osterholz et al., 2016).

(iv) Determine how climate change-related drivers, such as warming, intermediate and deep-water formation, global thermohaline circulation, acidification and deoxygenation might affect rDOC production/degradation from a multistressors perspective.

(v) Test via FT-IC-MS (Lehmann et al., 2020) whether the molecular diversity (number of molecular formulas) of bulk rDOC is too high to make it energetically rewarding to degrade, despite that the individual compounds might be easily degraded, as suggested for soil organic matter (Lehmann et al., 2020).

(vi) Reconcile the calculations of theoretical extreme dilution $\left(10^{-12} \mathrm{~mol} \mathrm{~L}^{-1}\right)$ with the actual fraction of molecules at such concentrations in the deep ocean.

(vii) Investigate multi-substrate and low-concentration transport mechanisms in meso- and bathypelagic microorganisms by combining microbial rate measurements in situ with -omics approaches.

New knowledge gained in such studies will reduce the gap in our understanding of organic carbon sequestration. That knowledge is required for a robust prediction of the responses of the marine $\mathrm{C}$ cycle in the light of climate change. 


\section{DATA AVAILABILITY STATEMENT}

The original contributions presented in the study are included in the article/supplementary material, further inquiries can be directed to the corresponding author/s.

\section{AUTHOR CONTRIBUTIONS}

FB conceived the original idea. All authors contributed to the final version of the manuscript.

\section{REFERENCES}

Amon, R. M. W., and Benner, R. (1996). Bacterial utilization of different size classes of dissolved organic matter. Limnol. Oceanogr. 41, 41-51. doi: 10.4319/lo.1996. 41.1.0041

Arrieta, J. M., Mayol, E., Hansman, R. L., Herndl, G. J., Dittmar, T., and Duarte, C. M. (2015). Dilution limits dissolved organic carbon utilization in the deep ocean. Science 348, 331-333. doi: 10.1126/science.1258955

Bayer, B., Hansman, R. L., Bittner, M. J., Noriega-Ortega, B. E., Niggemann, J., Dittmar, T., et al. (2019). Ammonia-oxidizing archaea release a suite of organic compounds potentially fueling prokaryotic heterotrophy in the ocean. Environ. Microbiol. 21, 4062-4075. doi: 10.1111/1462-2920.14755

Bengtsson, M. M., Attermeyer, K., and Catalán, N. (2018). Interactive effects on organic matter processing from soils to the ocean: are priming effects relevant in aquatic ecosystems? Hydrobiologia 822, 1-17. doi: 10.1007/s10750-018-3672-2

Benner, R., and Amon, R. M. (2015). The size-reactivity continuum of major bioelements in the ocean. Ann. Rev. Mar. Sci. 7, 185-205. doi: 10.1146/annurevmarine-010213-135126

Benner, R., and Biddanda, B. (1998). Photochemical transformation of surface and deep marine dissolved organic matter: effects on bacterial growth. Limnol. Oceanogr. 43, 1373-1378. doi: 10.4319/lo.1998.43.6.1373

Bianchi, T. S. (2011). The role of terrestrially derived organic carbon in the coastal ocean: a changing paradigm and the priming effect. Proc. Natl. Acad. Sci. U.S.A. 108, 19473-19481. doi: 10.1073/pnas.1017982108

Bianchi, T. S., Cui, X., Blair, N. E., Burdige, D. J., Eglinton, T. I., and Galy, V. (2018). Centers of organic carbon burial and oxidation at the land-ocean interface. Organic Geochem. 115, 138-155. doi: 10.1016/j.orggeochem.2017.09.008

Boudreau, B. P., and Ruddick, B. R. (1991). On a reactive continuum representation of organic matter diagenesis. Am. J. Sci. 291, 507-538. doi: 10.2475/ajs.291.5. 507

Boyd, P. W., Claustre, H., Levy, M., Siegel, D. A., and Weber, T. (2019). Multifaceted particle pumps drive carbon sequestration in the ocean. Nature 568, 327-335. doi: 10.1038/s41586-019-1098-2

Broek, T. A., Walker, B. D., Guilderson, T. P., Vaughn, J. S., Mason, H. E., and McCarthy, M. D. (2020). Low molecular weight dissolved organic carbon: aging, compositional changes, and selective utilization during global ocean circulation. Global Biogeochem. Cycles 34:e2020GB006547.

Buesseler, K. O., Boyd, P. W., Black, E. E., and Siegel, D. A. (2020). Metrics that matter for assessing the ocean biological carbon pump. Proc. Natl. Acad. Sci. U.S.A. 117, 9679-9687. doi: 10.1073/pnas.1918114117

Carlson, C. A., Giovannoni, S. J., Hansell, D. A., Goldberg, S. J., Parsons, R., and Vergin, K. (2004). Interactions among dissolved organic carbon, microbial processes, and community structure in the mesopelagic zone of the northwestern Sargasso Sea. Limnol. Oceanogr. 49, 1073-1083. doi: 10.4319/lo. 2004.49.4.1073

Carlson, C. A., Hansell, D. A., Nelson, N. B., Siegel, D. A., Smethie, W. M., Khatiwala, S., et al. (2010). Dissolved organic carbon export and subsequent remineralization in the mesopelagic and bathypelagic realms of the North Atlantic basin. Deep Sea Res. Part II Topical Stud. Oceanogr. 57, 1433-1445. doi: 10.1016/j.dsr2.2010.02.013

\section{FUNDING}

XA-S, JA, and FB were funded by projects FLUXES (CTM201569392-C3) and e-IMPACT (PID2019-109084RB-C2) from the Spanish "Plan Nacional de I+D" and co-funded with FEDER funds, FB by an Austrian Science Fund (project \# AP3430411/21), and JA by project SUMMER (AMD817806-5) from the European Union's Horizon 2020 Research and Innovation Programme. DH was supported by U.S. National Science Foundation Grant OCE 1634250 and NASA Grant 80 NSSC18K0437. GH by an Austrian Science Fund (project \# P28781-B21).

Catalán, N., Kellerman, A. M., Peter, H., Carmona, F., and Tranvik, L. J. (2015). Absence of a priming effect on dissolved organic carbon degradation in lake water. Limnol. Oceanogr. 60, 159-168. doi: 10.1002/lno.10016

Dittmar, T. (2015). "Reasons behind the long-term stability of dissolved organic matter," in Biogeochemistry of Marine Dissolved Organic Matter, ed. C. A. Carlson (Amsterdam: Elsevier), 369-388. doi: 10.1016/b978-0-12-405940-5. 00007-8

Dolfing, J., Jiang, B., Henstra, A. M., Stams, A. J., and Plugge, C. M. (2008). Syntrophic growth on formate: a new microbial niche in anoxic environments. Appl. Environ. Microbiol. 74, 6126-6131. doi: 10.1128/aem.01428-08

Druffel, E. R. M., Williams, P. M., Bauer, J. E., and Ertel, J. R. (1992). Cycling of dissolved and particulate organic matter in the open ocean. J. Geophys. Res. 97, 15639-15659. doi: 10.1029/92jc01511

Friedlingstein, P., Jones, S., Sitch, S., Tans, P., Arneth, A., Boden, T., et al. (2019). Global carbon budget 2014. Earth Syst. Sci Data 7:4785.

Geuer, J. K., Krock, B., Leefmann, T., and Koch, B. P. (2019). Quantification, extractability and stability of dissolved domoic acid within marine dissolved organic matter. Mar. Chem. 215:103669. doi: 10.1016/j.marchem.2019.103669

Hansell, D. A. (2013). Recalcitrant dissolved organic carbon fractions. Ann. Rev. Mar. Sci. 5, 421-445. doi: 10.1146/annurev-marine-120710-100757

Hansell, D. A., and Carlson, C. A. (2013). Localized refractory dissolved organic carbon sinks in the deep ocean. Global Biogeochem. Cycles 27, 705-710. doi: 10.1002/gbc. 20067

Hansell, D. A., and Carlson, C. A. (2014). Biogeochemistry of Marine Dissolved Organic Matter. Cambridge, MA: Academic Press.

Hansman, R. L., Dittmar, T., and Herndl, G. J. (2015). Conservation of dissolved organic matter molecular composition during mixing of the deep water masses of the northeast Atlantic Ocean. Mar. Chem. 177, 288-297. doi: 10.1016/j. marchem.2015.06.001

Hawkes, J. A., Rossel, P. E., Stubbins, A., Butterfield, D., Connelly, D. P., Achterberg, E. P., et al. (2015). Efficient removal of recalcitrant deep-ocean dissolved organic matter during hydrothermal circulation. Nat. Geosci. 8, 856860. doi: $10.1038 /$ ngeo 2543

Hedges, J. I., Baldock, J. A., Gélinas, Y., Lee, C., Peterson, M., and Wakeham, S. G. (2001). Evidence for non-selective preservation of organic matter in sinking marine particles. Nature 409, 801-804. doi: 10.1038/35057247

Hertkorn, N., Benner, R., Frommberger, M., Schmitt-Kopplin, P., Witt, M., Kaiser, K., et al. (2006). Characterization of a major refractory component of marine dissolved organic matter. Geochimica Cosmochimica Acta 70, 2990-3010. doi: 10.1016/j.gca.2006.03.021

Jiao, N., Herndl, G. J., Hansell, D. A., Benner, R., Kattner, G., Wilhelm, S. W., et al. (2010). Microbial production of recalcitrant dissolved organic matter: long-term carbon storage in the global ocean. Nat. Rev. Microbiol. 8, 593-599. doi: $10.1038 /$ nrmicro2386

Keil, R., and Mayer, L. (2014). "Mineral matrices and organic matter," in Treatise on Geochemistry, 2nd Edn, eds K. Turekian and H. Holland (Amsterdam: Elsevier), 337-359. doi: 10.1016/b978-0-08-095975-7.01024-x

Koehler, B., Von Wachenfeldt, E., Kothawala, D., and Tranvik, L. J. (2012). Reactivity continuum of dissolved organic carbon decomposition in lake water. J. Geophys. Res. Biogeosci. 117:G01024. doi: 10.1029/2011JG001793 
Kothawala, D. N., Kellerman, A. M., Catalán, N., and Tranvik, L. J. (2020). Organic matter degradation across ecosystem boundaries: the need for a unified conceptualization. Trends Ecol. Evol. 36, 113-122. doi: 10.1016/j.tree.2020.10. 006

Lechtenfeld, O. J., Hertkorn, N., Shen, Y., Witt, M., and Benner, R. (2015). Marine sequestration of carbon in bacterial metabolites. Nat. Commun. 6:6711.

Lechtenfeld, O. J., Kattner, G., Flerus, R., McCallister, S. L., Schmitt-Kopplin, P., and Koch, B. P. (2014). Molecular transformation and degradation of refractory dissolved organic matter in the Atlantic and Southern Ocean. Geochimica Cosmochimica Acta 126, 321-337. doi: 10.1016/j.gca.2013.11.009

Legendre, L., Rivkin, R. B., Weinbauer, M. G., Guidi, L., and Uitz, J. (2015). The microbial carbon pump concept: potential biogeochemical significance in the globally changing ocean. Prog. Oceanogr. 134, 432-450. doi: 10.1016/j.pocean. 2015.01.008

Lehmann, J., Hansel, C. M., Kaiser, C., Kleber, M., Maher, K., Manzoni, S., et al. (2020). Persistence of soil organic carbon caused by functional complexity. Nat. Geosci. 13, 529-534. doi: 10.1038/s41561-020-0612-3

Lønborg, C., and Álvarez-Salgado, X. A. (2012). Recycling versus export of bioavailable dissolved organic matter in the coastal ocean and efficiency of the continental shelf pump. Global Biogeochem. Cycles 26:GB3018.

Lønborg, C., Álvarez-Salgado, X. A., Letscher, R. T., and Hansell, D. A. (2018). Large stimulation of recalcitrant dissolved organic carbon degradation by increasing ocean temperatures. Front. Mar. Sci. 4:436. doi: 10.3389/fmars.2017. 00436

Lønborg, C., Cuevas, L. A., Reinthaler, T., Herndl, G. J., Gasol, J. M., Morán, X. A. G., et al. (2016). Depth dependent relationships between temperature and ocean heterotrophic prokaryotic production. Front. Mar. Sci. 3:90. doi: 10.3389/fmars.2016.00090

Lopez, C. N., Robert, M., Galbraith, M., Bercovici, S. K., Orellana, M. V., and Hansell, D. A. (2020). High temporal variability of total organic carbon in the deep northeastern Pacific. Front. Earth Sci. 8:80. doi: 10.3389/feart.2020.00080

Lützow, M. V., Kögel-Knabner, I., Ekschmitt, K., Matzner, E., Guggenberger, G., Marschner, B., et al. (2006). Stabilization of organic matter in temperate soils: mechanisms and their relevance under different soil conditions-a review. Eur. J. Soil Sci. 57, 426-445. doi: 10.1111/j.1365-2389.2006.00809.x

Martínez-Pérez, A. M., Álvarez-Salgado, X. A., Arístegui, J., and NietoCid, M. (2017). Deep-ocean dissolved organic matter reactivity along the Mediterranean Sea: does size matter? Sci. Rep. 7:5687.

Middelburg, J. J., Vlug, T., Jaco, F., and Van der Nat, W. (1993). Organic matter mineralization in marine systems. Glob. Planet. Change 8, 47-58. doi: 10.1016/ 0921-8181(93)90062-s

Mopper, K., Kieber, D. J., and Stubbins, A. (2015). "Marine photochemistry of organic matter: processes and impacts," in Biogeochemistry of Marine Dissolved Organic Matter, ed. C. A. Carlson (Amsterdam: Elsevier), 389-450. doi: 10. 1016/b978-0-12-405940-5.00008-x

Obernosterer, I., Reitner, B., and Herndl, G. J. (1999). Contrasting effects of solar radiation on dissolved organic matter and its bioavailability to marine bacterioplankton. Limnol. Oceanogr. 44, 1645-1654. doi: 10.4319/lo.1999.44. 7.1645

Ogura, N. (1970). On the presence of $0.1-0.5 \mu \mathrm{m}$ dissolved organic matter in seawater. Limnol. Oceanogr. 15, 476-479. doi: 10.4319/lo.1970.15.3.0476

Ogura, N. (1972). "Decomposition of dissolved organic matter derived from dead phytoplankton," in Biological Oceanography of the Northern Pacific Ocean, ed. Y. A. Takenouti (Tokyo: Idemitsu Shoten), 507-515.

Osterholz, H., Niggemann, J., Giebel, H.-A., Simon, M., and Dittmar, T. (2015). Inefficient microbial production of refractory dissolved organic matter in the ocean. Nat. Commun. 6:7422.

Osterholz, H., Singer, G., Wemheuer, B., Daniel, R., Simon, M., Niggemann, J., et al. (2016). Deciphering associations between dissolved organic molecules and bacterial communities in a pelagic marine system. ISME J. 10, 1717-1730. doi: 10.1038/ismej.2015.231

Patriarca, C., Balderrama, A., Može, M., Sjöberg, P. J., Bergquist, J., Tranvik, L. J., et al. (2020). Investigating the ionization of dissolved organic matter by electrospray. Anal. Chem. 92, 14210-14218. doi: 10.1021/acs.analchem. 0c03438

Penniston, J. T. (1971). High hydrostatic pressure and enzymic activity: inhibition of multimeric enzymes by dissociation. Arch. Biochem. Biophys. 142, 322-332. doi: 10.1016/0003-9861(71)90290-6

Perdue, E., and Benner, R. (2009). "Marine organic matter," in Biophysico-Chemical Processes Involving Natural Nonliving Organic Matter in Environmental Systems, eds B. Xing, N. Senesi, and P. M. Huang (Hoboken, NJ: John Wiley and Sons), 407-449.

Petras, D., Minich, J. J., Cancelada, L. B., Torres, R. R., Kunselman, E., Wang, M., et al. (2021). Non-targeted tandem mass spectrometry enables the visualization of organic matter chemotype shifts in coastal seawater. Chemosphere 27:129450. doi: 10.1016/j.chemosphere.2020.129450

Shen, Y., and Benner, R. (2018). Mixing it up in the ocean carbon cycle and the removal of refractory dissolved organic carbon. Sci. Rep. 8: 2542.

Shen, Y., and Benner, R. (2020). Molecular properties are a primary control on the microbial utilization of dissolved organic matter in the ocean. Limnol. Oceanogr. 65, 1061-1071. doi: 10.1002/lno.11369

Sichert, A., Corzett, C. H., Schechter, M. S., Unfried, F., Markert, S., Becher, D., et al. (2020). Verrucomicrobia use hundreds of enzymes to digest the algal polysaccharide fucoidan. Nat. Microbiol. 5, 1026-1039. doi: 10.1038/s41564020-0720-2

Sun, L., Xu, C., Lin, P., Quigg, A., Chin, W.-C., and Santschi, P. H. (2021). Photooxidation of proteins facilitates the preservation of high molecular weight dissolved organic nitrogen in the ocean. Mar. Chem. 229:103907. doi: 10.1016/ j.marchem.2020.103907

Vähätalo, A. V., Aarnos, H., and Mäntyniemi, S. (2010). Biodegradability continuum and biodegradation kinetics of natural organic matter described by the beta distribution. Biogeochemistry 100, 227-240. doi: 10.1007/s10533-0109419-4

Valentine, D. L., Kessler, J. D., Redmond, M. C., Mendes, S. D., Heintz, M. B., Farwell, C., et al. (2010). Propane respiration jump-starts microbial response to a deep oil spill. Science 330, 208-211. doi: 10.1126/science.119 6830

Walker, B. D., Beaupré, S. R., Guilderson, T. P., McCarthy, M. D., and Druffel, E. R. (2016). Pacific carbon cycling constrained by organic matter size, age and composition relationships. Nat. Geosci. 9, 888-891. doi: 10.1038/ngeo 2830

Ward, N. D., Keil, R. G., Medeiros, P. M., Brito, D. C., Cunha, A. C., Dittmar, T., et al. (2013). Degradation of terrestrially derived macromolecules in the Amazon River. Nat. Geosci. 6, 530-533. doi: 10.1038/ngeo1817

Williams, P. J. (2000). "Heterotrophic bacteria and the dynamics of dissolved organic material," in Microbial Ecology of the Oceans, eds D. L. Kirchman and J. M. Gasol (New York, NY: Wiley-Liss), 153-200.

Zakem, E. J., Cael, B., and Levine, N. M. (2021). A unified theory for organic matter accumulation. Proc. Natl. Acad. Sci. 118:e2016896118. doi: 10.1073/ pnas. 2016896118

Zark, M., and Dittmar, T. (2018). Universal molecular structures in natural dissolved organic matter. Nat. Commun. 9:3178.

Conflict of Interest: The authors declare that the research was conducted in the absence of any commercial or financial relationships that could be construed as a potential conflict of interest.

Copyright (C) 2021 Baltar, Alvarez-Salgado, Arístegui, Benner, Hansell, Herndl and Lønborg. This is an open-access article distributed under the terms of the Creative Commons Attribution License (CC BY). The use, distribution or reproduction in other forums is permitted, provided the original author(s) and the copyright owner(s) are credited and that the original publication in this journal is cited, in accordance with accepted academic practice. No use, distribution or reproduction is permitted which does not comply with these terms. 